\title{
TRMM SATELLITE PERFORMANCE IN ESTIMATING RAINFALL OVER THE MIDWEST REGION OF BRAZIL
}

\author{
DANELICHEN, Victor Hugo de Morais \\ Programa de Pós-graduação em Física Ambiental, UFMT - Cuiabá/MT - Brasil \\ MACHADO, Nadja Gomes \\ Laboratório de Biologia da Conservação, IFMT - Cuiabá/MT - Brasil \\ Programa de Pós-graduação em Física Ambiental, UFMT - Cuiabá/MT - Brasil \\ SOUZA, Maísa Caldas \\ Programa de Pós-graduação em Física Ambiental, UFMT - Cuiabá/MT - Brasil \\ BIUDES, Marcelo Sacardi \\ Programa de Pós-graduação em Física Ambiental, UFMT - Cuiabá/MT - Brasil
}

\begin{abstract}
Rainfall is the key element in regional water balance, and have direct influence over economic activity. In this study, we evaluate the estimates of precipitation by TRMM satellite (Tropical Rainfall Measuring Mission) on the Midwest region of Brazil. The rainfall measured by TRMM satellite was compared with rainfall series obtained by the Office of Instituto de Controle de Espaço Aéreo (ICEA) of Comando da Força Aérea. The TRMM satellite overestimated annual rainfall between 0.6 and $37.4 \%$, with greater overestimation in the dry season. However, the rainfall estimate by TRMM satellite had a high correlation ( 0.88$)$ with the rainfall series and had high Willmott coefficient. The Northern of Brazilian Midwest had the highest annual accumulated rainfall and the Southwest and Northeast of Midwest had the lowest annual accumulated rainfall. There was a inverse seasonal pattern of accumulated rainfall, with higher values in the Northern of Midwest during the rainy season in the Southwest and Northeast during the dry season.
\end{abstract}

Key-words: satellite observations, data processing, climatology, hydrological cycle.

\begin{abstract}
RESUMO
DESEMPENHO DO SATÉLITE TRMM NA ESTIMATIVA DE PRECIPITAÇÃO SOBRE A REGIÃO CENTRO-OESTE

A precipitação é o elemento chave no balanço hídrico regional, tendo influência direta na atividade econômica. Nesse trabalho foram analisadas as estimativas da precipitação pelo satélite TRMM (Tropical Rainfall Measuring Mission) sobre a região Centro-Oeste do Brasil. A precipitação medida pelo satélite TRMM foi comparada com séries de precipitação obtidas pelo Instituto de Controle de Espaço Aéreo (ICEA) do Comando da Força Aérea. O satélite TRMM superestimou a precipitação anual entre 0,6 e 37,4\%, com maior superestimativa na estação seca. No entanto, teve alta correlação com a série medida $(0,88)$ e alto coeficiente de Willmott $(0,92)$. O norte do Centro-Oeste brasileiro teve maior precipitação acumulada anual e o sudeste e noroeste do Centro-Oeste teve menor precipitação acumulada anual. Houve padrão sazonal inverso da precipitação acumulada, com maiores valores no norte do Centro-Oeste na estação chuvosa e no sudeste do CentroOeste na estação seca.
\end{abstract}

Palavras-chave: observações de satélite, processamento de dados, climatologia, ciclo hidrológico. 


\section{INTRODUCTION}

The rainfall is one of the most influential meteorological element on environmental conditions (DALLACORT et al., 2011) with a direct effect on the water balance and indirect effect on air and soil temperature, and relative humidity that overall affect plant growth and development (SANTOS, 2005). The amount and distribution of rainfall that occur annually in a region determine the type of natural vegetation and also the predominant agricultural exploitation mode (BURIOL et al., 2007). The characterization of rainfall permits better planning of agricultural practices and soil conservation structures (contour lines and terraces), constructions (channel drains, dams), and hydraulic structures, as well as weather forecasts (BAZZANO et. al., 2007).

Middle West region of Brazil has an economy based on agribusiness involving production chain of agricultural and cattle raising. The lack or excess rainfall is a factor that directly influences the agribusiness development which can cause partial and total losses (DALLACORT et. al., 2011). Thus it is crucial to analyze the pluviometric regime that depends on a long series of data (MARCUZZO et al., 2012). The use of satellite sensors in rainfall estimation has shown to be an important alternative for environmental studies by increasing the amount of available information (NOBREGA et al., 2008).

Remote sensing techniques are advantageous because they allow monitoring on a regional scale the partitioning of energy and rainfall distribution, with low operating costs and greater data acquisition (COURAULT et al., 2005; ALLEN et al., 2011). Remote sensing data, especially in polar orbits satellites provide continuous spatial and temporal information on vegetated surfaces for measurement and monitoring of biophysical variables affecting the surface energy balance, including albedo, biome type and vegetation indices (MU et al., 2011). As a result, it has become a powerful tool for obtaining information necessary for the natural resources management such as water, soil and vegetation (BRAGA et al., 2009).

Several methodologies have been proposed for rainfall estimation using satellite images. These methodologies are based on maps from satellites that cover bands of the electromagnetic spectrum. Among these satellites stand out the GOES series (Geoestationary Operational Environmental System), and Tropical Rainfall Measuring Mission satellite (TRMM), which has the specific purpose of measuring rainfall in the tropics (COLLISCHONN et al., 2007).

TRMM satellite developed by USA and Japan has a heliocentric orbit and five instruments on board: Microwave Imager (TMI) precipitation radar (PR), radiometer in the visible and infrared (VIRS), sensor radiant energy from the surface of the earth and clouds (CERES) and lightning sensor for imaging (LIS), (KUMMEROW et al., 2000). Besides these instruments estimates are validated with data obtained in the field (Ground Validation - GV), with weather radar at several stations along the intertropical belt of the globe and measurements taken on the ground.

Remote sensing techniques are used to investigate pluviometric regime dynamics for many purposes such as: mapping flood dynamics of the Pantanal with multi-spectral images from radar ALOS/PALSAR and RADARSAT-2 (EVANS et al., 2010), assessing the spatiotemporal dynamics 
of two sub-regions of the Pantanal biome with rainfall data from TRMM (ADAMI et al., 2008), studying daily variability of rainfall in the Amazon basin with rainfall data estimated by S-POL radar (S-band) algorithm for the 3B42-V6 TRMM satellite (SILVA et al., 2011), evaluate the vegetation response in northeastern Brazil with precipitation data from TRMM and data generated by the Moderate Resolution Imaging Spectroradiometer (MODIS) to Caatinga, Cerrado and forest biomes (ARAI et al., 2009), identifying warm season in urban regions of Atlanta, Georgia, Montgomery, Alabama, Nashville, Tennessee, San Antonio, Waco, Dallas, and Texas from 1998 to 2000 with data from the TRMM and PR radars (SHEPHERD et al., 2002), investigate flooding causes in a city in south Brazil (COLLISCHONN, 2010). Dinku et al. (2007) has validated rainfall products of TRMM satellite over the Ethiopian highlands.

There is little or no availability of data related to rainfall in Brazil (MELLO et al., 2009). Thus the objective of this study was to evaluate the estimates of precipitation from TRMM satellite over the Midwest region in Brazil comparing to measured data in terrestrial stations installed at five airports.

\section{MATERIAL AND METHODS}

\subsection{Study area and meteorological data}

Data were obtained from 05 meteorological stations installed at airports in the Midwest region in Brazil which is composed by Mato Grosso state, Mato Grosso do Sul, Goiás and Distrito Federal (Figure 1). We considered dry season from April to September. Data were provided by the Instituto de Controle de Espaço Aéreo (ICEA) of Comando da Força Aérea that is available on the website [http://clima.icea.gov.br/clima/]. Data ranges from 2000 to 2010 were used.

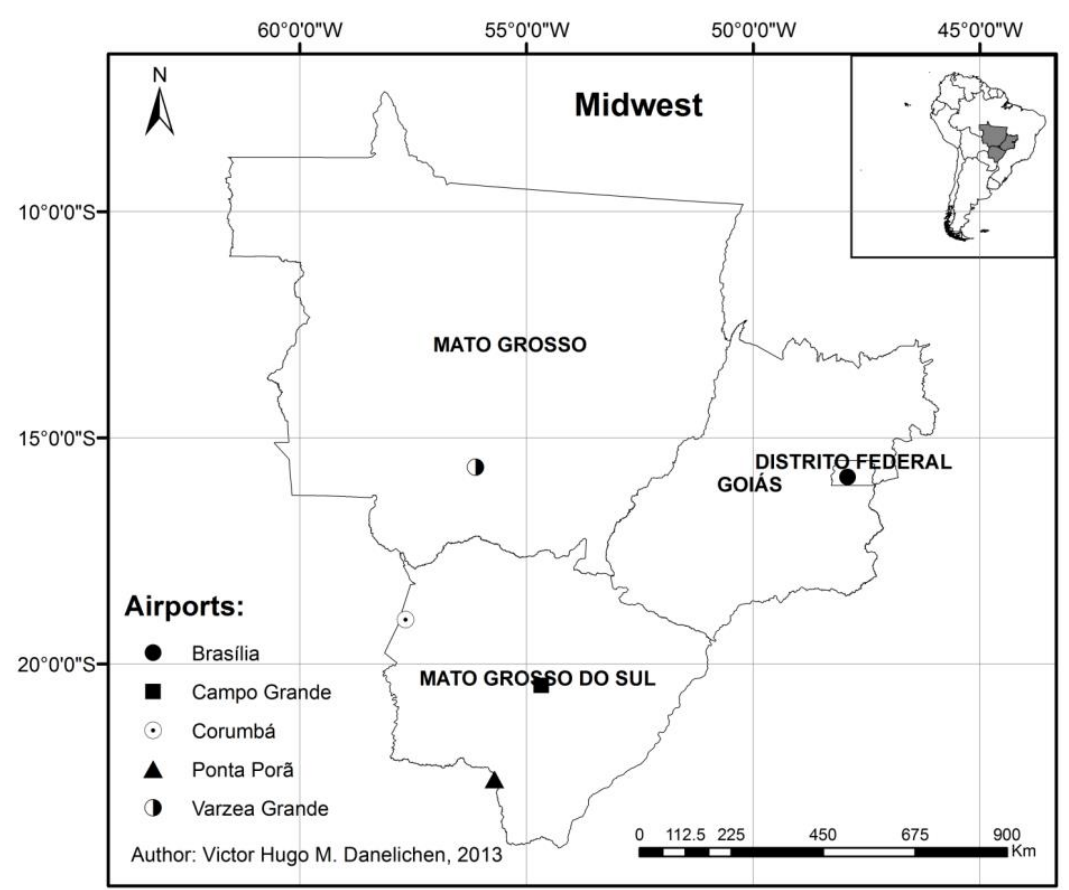

Figure 1 - The Location of 05 airports in states from Midwest Brazilian region. 


\subsection{TRMM data}

The rainfall data from study area were obtained from TRMM satellite (Tropical Rainfall Measuring Mission), provided by Distributed Active Archive System (DAAC) that is available on the website [http://disc2.nascom.nasa.gov/Giovanni/tovas/TRMM]. The pixel size of TRMM is $25 \mathrm{~km}^{2}$. We used data from 3B43 V6 products.

\subsection{Statistical indices}

The evaluation of rainfall estimates from TRMM data in relation to measured data was performed by these statistical indices: accuracy of Willmott index "d" (eq. 1), root mean square error "RMSE" (eq. 2), mean absolute error "MAE" (eq. 3), and Spearman's Rank correlation (eq. 4).

The accuracy is related to the distance of the estimated values from those observed. Mathematically, this approximation is widely applied to the comparison between models (WILLMOTT et al., 1985). Their values range from the value of 0 , representing no agreement, to value of 1 representing perfect agreement.

$d=1-\left[\sum\left(P_{i}-O_{i}\right)^{2} / \sum\left(\left|P_{i}-O\right|+\left|O_{i}-O\right|\right)^{2}\right]$

where $P_{i}$ is the estimated value, $O_{i}$ the value observed and $O$ the average of observed values.

The RMSE indicates how the model fails to estimate the variability in the measurements around the mean and measures the change in the estimated values around the measured values (WILLMOTT \& MATSUURA, 2005). The lowest threshold of RMSE is 0 , which means there is complete adhesion between the TRMM estimates and measurements.

$E Q M=\sqrt{\frac{\sum\left(P_{i}-O_{i}\right)^{2}}{n}}$

The MAE indicates the mean absolute distance (deviation) of values estimated from the values measured. The MAE and RMSE values should be close to zero (WILLMOTT \& MATSUURA, 2005).

$E M A=\sum \frac{\left|P_{i}-O_{i}\right|}{n}$

Spearman's Rank correlation coefficient is used to identify and test the strength of a relationship between two sets of data.

$r=1-\frac{6 \sum d^{2}}{n\left(n^{2}-1\right)}$

where $d_{i}=x_{i}-y_{i}$ is the difference in the ranks given to the two variable values for each item of data.

\section{RESULTS AND DISCUSSION}

In general the TRMM satellite has overestimated the rainfall in $19.4 \%$ (Table 1). The highest overestimation was at Ponta Porã airport $(37.4 \%)$ and the lowest was at Campos Grande airport (0.6\%). The highest values were overestimated by TRMM satellite in dry season (20.1\%). The wet season was $68.6 \%$ and $55.3 \%$ higher than dry season in 
measured and estimated rainfall, respectively. The Campo Grande airport had the higher accumulated rainfall values and the Ponta Porã airport had the lower ones.

\begin{tabular}{|c|c|c|c|c|c|c|}
\hline \multirow[b]{2}{*}{ Airport } & \multicolumn{3}{|c|}{ Measured rainfall $(\mathbf{m m})$} & \multicolumn{3}{|c|}{ Estimated rainfall $(\mathrm{mm})$} \\
\hline & Annual & $\begin{array}{c}\text { Wet } \\
\text { season }\end{array}$ & $\begin{array}{c}\text { Dry } \\
\text { season }\end{array}$ & Annual & $\begin{array}{c}\text { Wet } \\
\text { season }\end{array}$ & $\begin{array}{c}\text { Dry } \\
\text { season }\end{array}$ \\
\hline Várzea Grande & 1259.70 & 118.14 & 86.40 & 1510.93 & 141.92 & 107.20 \\
\hline Corumbá & 786.64 & 69.82 & 60.82 & 1080.55 & 98.03 & 83.88 \\
\hline Campo Grande & 1378.26 & 111.64 & 112.04 & 1386.57 & 119.61 & 109.09 \\
\hline Ponta Porã & 956.84 & 90.32 & 71.48 & 1528.23 & 136.29 & 118.43 \\
\hline Brasília & 1261.88 & 111.69 & 87.81 & 1342.50 & 123.43 & 105.67 \\
\hline
\end{tabular}

Table 1 - Annual and seasonal variability of measured and estimated rainfall to the Midwest Brazilian region.

The Campo Grande airport had lower errors and higher Willmott index and correlation, by the other hand Ponta Porã airport had an inverse pattern (Table 2). Although there was overestimation of estimated rainfall by TRMM satellite, it has estimated appropriately the annual accumulated rainfall due to show correlations over $88 \%$ and Willmott index greater than 0.92 which is an approximation in almost perfect measurements of rain gauges. There was no failure in the time series in this study. Thus, an important advantage of rainfall data from satellite is the insignificant number of failures in time series.

\begin{tabular}{lcccc}
\hline Airport & MAE & RMSE & d & Correlation \\
\hline Várzea Grande & 22.15 & 56.42 & 0.96 & $0.88 * * *$ \\
Corumbá & 25.58 & 45.70 & 0.95 & $0.88 * * *$ \\
Campo Grande & 2.63 & 38.77 & 0.98 & $0.91 * * *$ \\
Ponta Porã & 46.43 & 71.02 & 0.92 & $0.82 * * *$ \\
Brasília & 14.73 & 56.89 & 0.96 & $0.89 * * *$ \\
\hline
\end{tabular}

Table 2 - Statistical indicators of the relation between measured and estimated rainfall to the Midwest Brazilian region. $*, p<0,05 ; * *, p<0,01 ; * * *, p<0,001$.

The monthly variability of accumulated rainfall was appropriate estimated by the TRMM satellite (Figure 2). The Campo Grande airport had the best TRMM rainfall estimates and the Ponta Porã airport the worst. There was a tendency of the estimated rainfall by TRMM satellite to be ahead of the measured one. This time lag between the estimate of satellite measurements in the study areas had already been observed in studies by Collischon (2006) where analyzes were performed in São Francisco and Tapajós basins. Although not yet fully explained the cause of this time lag, it may possibly be related to some handling error, both the read gauges and generating estimates of the satellite as the satellite predict the tendency of rainfall before it happens (NOBREGA et al., 2008). 

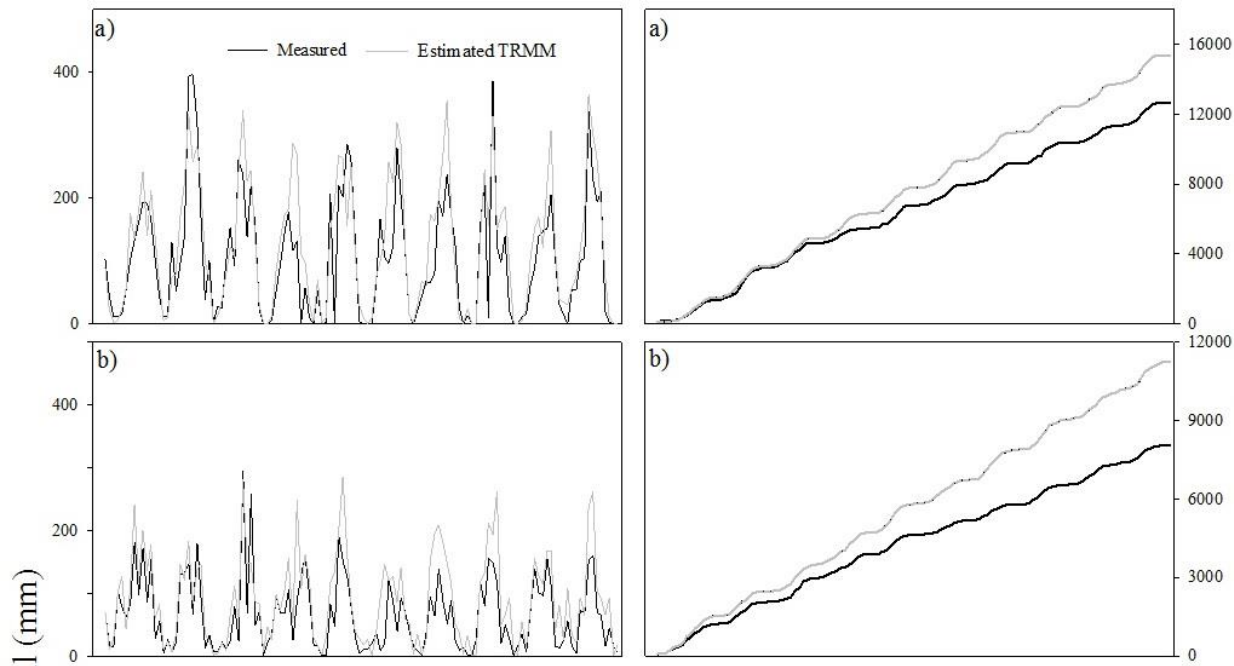

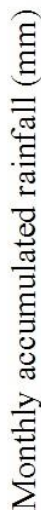
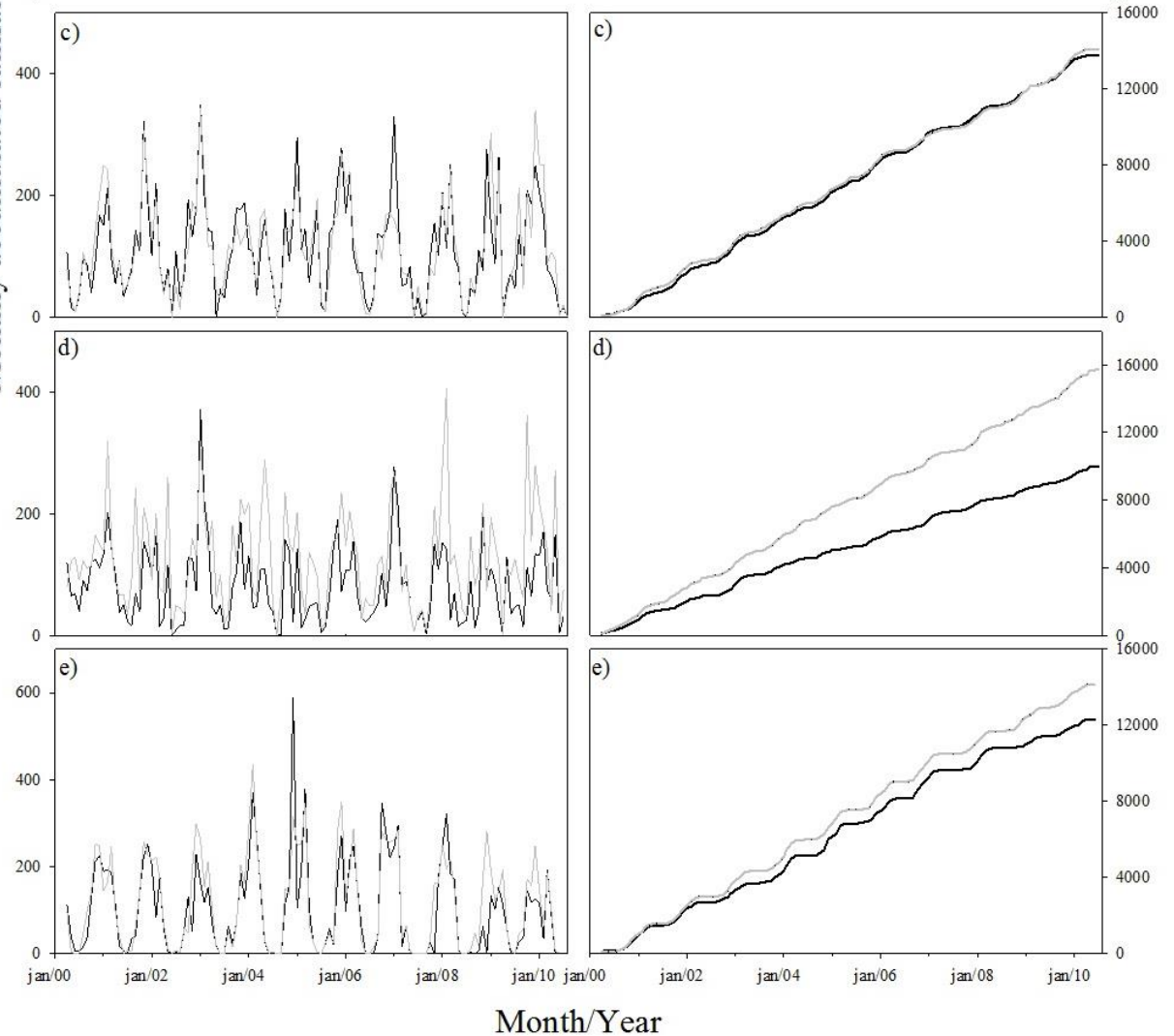

Figure 2 - Monthly variability of (left side) and time lag between measured and estimated rainfall (right side) in the Midwest Brazilian region from 2000 to 2010. Airports: Várzea Grande/MT (a), Corumbá/MS (b), Campo Grande/MS (c), Ponta Porã/MS (d), Brasília/DF (e).

Annually the North was the wettest while the Southwest and Northeast were the drier places of the Midwest Brazilian region from 2000 to 2010 (Figure 3). 


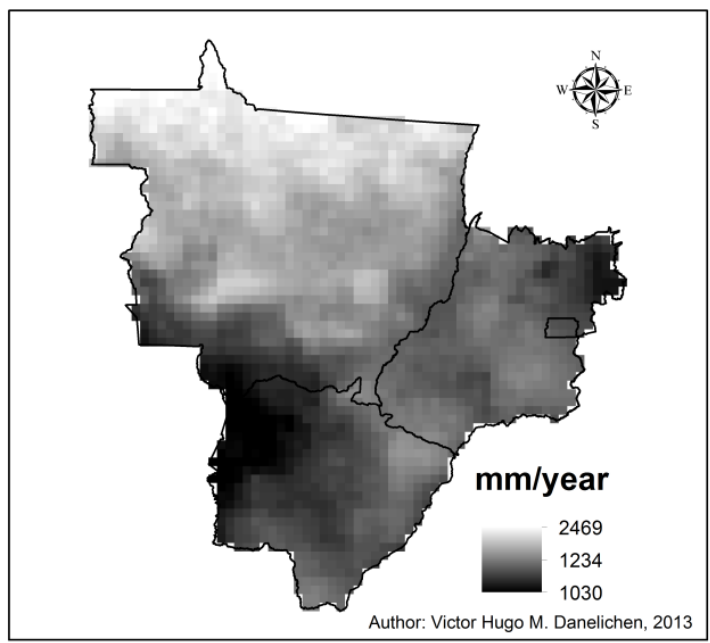

Figure 3 - Spatial variability of estimated rainfall by TRMM satellite in the Midwest Brazilian region from 2000 to 2010.

In the Midwest region the atmospheric mechanism is the main regional factor which maintains climatic homogeneity while altitudinal and latitudinal variations maintain heterogeneity (JUNIOR \& SILVA, 2012). Thus all climatic factors such as the relief interact to the regional system of atmospheric circulation determining the climate over a region (NIMER, 1989). The rainfall regime in the Midwest region is mainly due to atmospheric circulation systems (JUNIOR \& SILVA, 2012). By the other hand, the topography of the region influence very little on the distribution of rainfall, with no interference in the general trends determined by climatic factors (JUNIOR \& SILVA, 2012).

In the dry season the Northeast was the driest place while the South was wetter (Figure 4). It is noteworthy that there was an inverse climatic pattern between the North and South in the Midwest Brazilian region. 


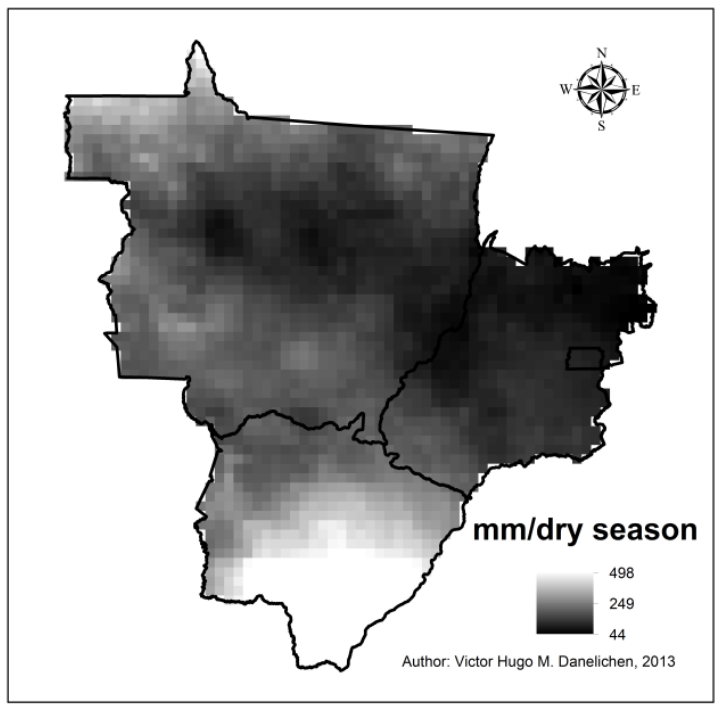

Figure 4 - Dry season effect in the spatial variability of estimated rainfall by TRMM satellite in the Midwest Brazilian region from 2000 to 2010.

In the wet season the Northeast was the wettest place while the Southwest was drier (Figure 4).

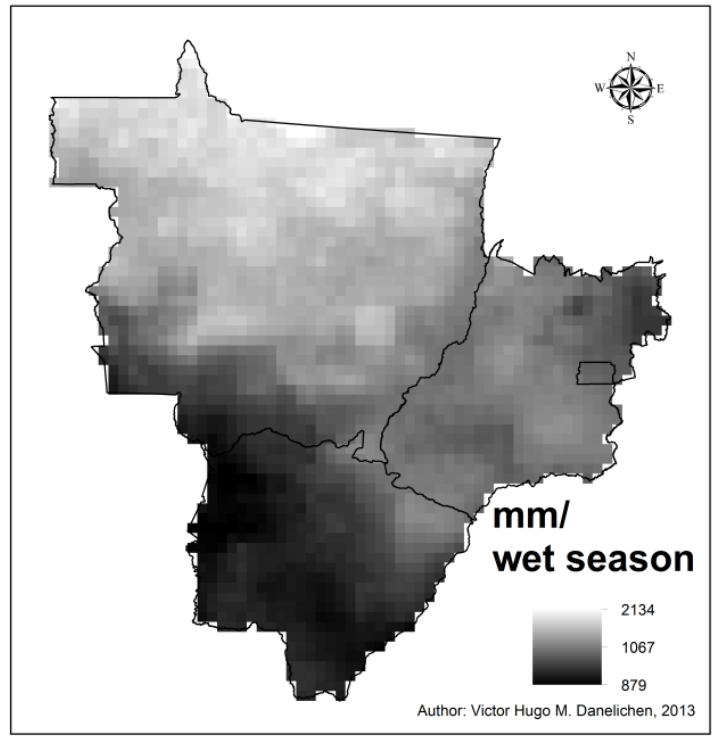

Figure $\mathbf{5}$ - Wet season effect in the spatial variability of estimated rainfall by TRMM satellite in the Midwest Brazilian region from 2000 to 2010.

Midwest rainfall regime is tropical and over $70 \%$ of the total accumulated rainfall precipitates from November to March, being generally the wetter trimester January-March in the North, December-February in the Center, and November-January in the South (JUNIOR \& SILVA, 2012). During the wet trimester it rains from 45 to $55 \%$ of total annual, except in the South (NIMER, 1989). In contrast, the winter is very dry and not only the winter trimester is dry as well as one month before (May) and one month after (September) (JUNIOR \& SILVA, 2012). 


\section{CONCLUSION}

Although there was overestimation of estimated rainfall by TRMM satellite, it has estimated appropriately the annual accumulated rainfall due to showed correlations over $88 \%$ and Willmott index greater than 0.92. Annually the North was the wettest while the Southwest and Northeast were the drier places of the Midwest Brazilian region. In the dry season the Northeast was the driest place while the South was wetter. There was an inverse climatic pattern between the North and South in the Midwest Brazilian region.

\section{REFERENCES}

ADAMI, M.; FREITAS, R. M.; PADOVANI, C. R.; SHIMABUKURO, Y. E.; MOREIRA, A. M. 2008. Estudo da dinâmica espaço-temporal do bioma Pantanal por meio de imagens MODIS. Pesquisa Agropecuária Brasileira 43(10): 1371-1378.

ALLEN, R.; IRMAK, A.; TREZZA, R.; HENDRICKX, J.M.H.; BASTIAANSSEN. W.; KJAERSGAARD. J. 2011. Satellite-based ET estimation in agriculture using SEBAL and METRIC. Hydrological Processes 25: 4011-4027.

ARAI, E.; ADAMI, M.; FREITAS, R. M.; SHIMABUKURO, Y. E.; RAO, V. B.; MOREIRA, M. A. Análise de Séries Temporais MODIS e TRMM nas áreas de caatinga, cerrado e floresta. Anais XIV Simpósio Brasileiro de Sensoriamento Remoto, Natal, Brasil, 25-30 abril 2009, INPE, p. 5081-5088.

BAZZANO, M. G. P.; ELTZ, F. L. F.; CASSOL, E. A. Erosividade, coeficiente de chuva, padrões e período de retorno das chuvas de Quaraí, RS. Revista Brasileira de Ciência do Solo, Campinas, SP, v. 31, n. 5, p. 1205-1217, 2007.

BRAGA, C. C; SOARES, F. R; DANTAS, F. R. C; BARBIERI, L. F. P. Determinação do albedo e índice de área foliar usando o sensor TM / LANDSAT 5. Anais XIV Simpósio Brasileiro de Sensoriamento Remoto, Natal, Brasil, 25-30 abril 2009, INPE, p. 935-942.

BURIOL, G. A.; ESTEFANEL, V.; CHAGAS, A. C.; EBERHARD, T. D. 2007. Clima e vegetação natural do Estado do Rio Grande do Sul segundo o diagrama climático de Walter e Lieth. Ciência Florestal 17 (2): 91-100.

COLLISCHON, E. 2010. Climatologia e Gestão do espaço urbano o caso de uma cidade pequena. Mercator 9 (1): 53-70.

COLLISCHONN, B. 2006. Uso de precipitação estimada pelo satélite TRMM em modelo hidrológico distribuído. Dissertação de Mestrado. Universidade Federal do Rio Grande do Sul.

COLLISCHONN, B.; ALLASIA, D.; COLLISCHONN, W.; TUCCI, C.E.M. 2007. Desempenho do satélite TRMM na estimativa de precipitação sobre a bacia do Paraguai superior. Revista Brasileira de Cartografia, 59(01): 93-99.

COURAULT, D.; SGUIN, B.; OLIOSO, A. 2005. Review on estimation of evapotranspiration from remote sensing data: from empirical to numerical modeling approaches. Irrigation and Drainage System 19: 223-249.

DALLACORT, R.; MARTINS, J. A.; INOUE, H. M.; FREITAS, P. S. L.; COLETTI, A. J. 2011. Distribuição das chuvas no município de Tangará da Serra, médio norte do Estado de Mato Grosso, Brasil. Acta Scientiarum Agronomy 33(2): 193-200.

DINKU, T.; CECCATO, P.; GROVER-KOPEC, E.K.; LEMMA, M.; CONNOR, S.J.; ROPELEWSKI, C.F. 2007. Validation of satellite rainfall products over East Africa's complex topography. International Journal of Remote Sensing 28(7): 15031526.

EVANS, T. L.; COSTA. M.; TELMER. K.; SILVA, T. S. F. 2010. Using ALOS/PALSAR and RADARSAT-2 to Map Land Cover and Seasonal Inundation in the Brazilian Pantanal. IEEE Journal of elected topics in applied earth observations and remote sensing 3(4): 560-575. 
JUNIOR, S. C. P.; SILVA, A. S. 2012. A dinâmica climática do Mato Grosso do Sul e as queimadas do ano de 2009: uma análise tempero-espacial a partir das imagens do NOAA - 15. ACTA Geográfica, Ed. Esp. Climatologia Geográfica: 223-237. KUMMEROW, C.; SIMPSON, J.; THIELE, O.; BARNES, W.; CHANG, A. T. C.; STOCKER, E.;ADLER, R. F.; HOU, A.; KAKAR, R.; WENTZ, F.; ASHCROFT, P.; KOZU, T. HONG, Y.; OKAMOTO, K.; IGUCHI, T.; KUROIWA, H.; IM, E.; HADDAD, Z.; HUFFMAN, G.; FERRIER, B.; OLSON, W. S.; ZIPSER, E.; SMITH, E. A.; WILHEIT, T. T.; NORTH, G. KRISHNAMURTI, T.; NAKAMURA, K. 2000. The Status of the Tropical Rainfall Measuring Mission (TRMM) after Two Years in Orbit. Journal of Applied Meteorology 39: 1965-1982.

MARCUZZO, F. F. N.; OLIVEIRA, N. L.; FILHO, F. R. P.; FARIA, T.G. 2012. Chuvas na região Centro-Oeste e no estado do Tocantins: Análise histórica e Tendência futura. Boletim Geográfico 30(1): 19-30.

MELLO, C. R.; SILVA, A. M. 2009. Modelagem estatística da precipitação mensal e anual e no período seco para o estado de Minas Gerais. Revista Brasileira de Engenharia Agrícola e Ambiental 13(1): 68-74.

MU. Q.; ZHAO. M.; RUNNING. S.W. Improvements to a MODIS global terrestrial evapotranspiration algorithm. Remote Sensing of Environment. Numerical Terradynamic Simulation Group, Department of Ecosystem and Conservation Sciences, The University of Montana, Missoula, MT 59812, USA, 2011.

NIMER, E. Climatologia do Brasil. Rio de Janeiro: IBGE, 1989.

NÓBREGA, R.N. 2008. Modelagem de Impactos do Desmatamento nos Recursos Hídricos da Bacia do Rio Jamari (Ro) utilizando dados de Superfície e do TRMM. Campina Grande, PB: UFCG. 2008. 238 pág. Tese de Doutorado. Universidade Federal de Campina Grande.

SANTOS, J. W. M. C. 2005. Ritmo Climático e Sustentabilidade sócio-ambiental da agricultura comercial da soja no Sudeste de Mato Grosso. Revista do Departamento de Geografia 1: 1-20.

SHEPHERD, J. M.; PIERCE, H.; NEGRI, A. J. 2002 Rainfall Modification by Major Urban Areas: Observations from Spaceborne Rain Radar on the TRMM Satellite. American Meteorological Society. Journal of applied meteorology 41: 689-701.

SILVA, C. M. S.; FREITAS, S. R.; GIELOW, R. 2011. Ciclo diário da precipitação estimada através de um radar banda $S$ e pelo algoritmo 3B42_V6 do projeto TRMM durante a estação chuvosa de 1999 no sudoeste da Amazônia. Revista Brasileira de Meteorologia 26(1): 95-108.

WILLMOTT, C.J.; CKLESON, S.G.; DAVIS, R.E.; FEDDEMA, J.J.; KLINK, K.M.; LEGATES, D.R.; O'DONNELL, J.; ROWE, C.M. 1985. Statistics for the evaluation and comparison of models. Journal of Geophysical Research 90 (C5): 89959005.

WILLMOTT, C.J.; MATSSURA, K. 2005. Advantages of the mean absolute error (MAE) over the root mean square error (RMSE) in assessing average model performance. Climate Research 30: 79-92. 